\title{
Cytological Pattern of Cervical Papanicolaou Smear According to 2014 Bethesda System: A Study Conducted in Tertiary Care Central India, Indore
}

\author{
Authors \\ Dr Sachin Sharma, Prof. Dr C.V. Kulkarni, Prof. Dr Meena Mittal, Dr Rakesh Mehar, \\ Dr Ankesh Kumar Jain, Dr Priya Jain \\ Corresponding Author \\ Dr Priya Jain
}

\section{Introduction}

Cervical cancer ranked second among most commonly diagnosed cancer and in less developed countries it is third leading cause of cancer related death among females ${ }^{[1,2,3]}$ It is estimated that each year, 527,000 new case occur and 275, 000 deaths. Globally, $15 \%$ of all cancer in females is cervical cancer. ${ }^{[2,4]}$. In India about $20 \%$ of all cancer related deaths is due to cervical cancer in women and is the number one cause of death in middle aged Indian women. ${ }^{[5]}$ Also, India has 432.20 million women at risk for cervical cancer, annual number of cervical cancer cases is 122,844 , annual number of deaths is $67,4773 .^{[6]}$

Cancer cervix is a multifactorial disease. Major risk factors are age ${ }^{[7,8]}$, illiteracy, low socioeconomic status, early menarche, marital status, early marriage, early first childbirth, age at last child birth, multiparity, abortion, multiple sexual partners, late menopause, genital infection, poor genital hygiene, tobacco use, passive smoking and contraceptive use ${ }^{[9-13]}$. Other risk factors includes co-infection with Chlamydia trachomatis, non-use of condoms by partners and nutritional factors. ${ }^{[14-19]}$
Human Papilloma virus (HPV) infection is the most important risk factor. ${ }^{[20]}$ It has been shown recently that cervical cancer is strongly associated with the presence of high risk or oncogenic Human Papilloma virus (HPV) types (up to $100 \%){ }^{[21,22]}$

Cervical cancer is a potentially a preventable disease through early detection using several screening techniques. ${ }^{[23]}$ Therefore, the main focus is on the secondary prevention through early detection which is mainly done by cytology. This will lead to treatment of precancerous lesion itself before cancer develops hence reducing the incidence of cervical cancer. ${ }^{[24]}$ In Screening by cytology we look for pre- cancerous changes in the cervix that could develop into cervical cancer. $^{[3]} \quad$ Cytomorphologically abnormal epithelial cells are best demonstrated by the Papanicolaou test. The initial and most important step in cervical cancer screening was the introduction of Papanicolaou (Pap) testing ${ }^{[25,26]}$. The 2014 Bethesda System has been introduced recently, which is used for reporting cervical smear in our study. 


\section{Materials and Methods}

This study was conducted in Department of Pathology, Mahatma Gandhi Medical College and Maharaja Yeshwant Rao Hospital, Indore, Madhya Pradesh, India. It is a prospective study. The study duration was one year from July 2017 to June 2018 Sample size for the study was of 40 cases.

\section{Inclusion Criteria}

- Symptomatic Females after puberty having following signs and symptoms.

Signs and symptoms to be screened: as documented by FIGO (2009) ${ }^{[11]}$

- Abnormal vaginal bleeding, such as bleeding after vaginal intercourse, bleeding after menopause, bleeding and spotting between periods, and having (menstrual) periods that are longer or heavier than usual. Bleeding after douching or after a pelvic exam may also occur.

- Pain in the lower abdomen or pelvic region.

- An unusual discharge from the vagina - the discharge may contain some blood and may occur between your periods or after menopause.

- Pain during intercourse.

- Any cervical mass seen per speculum, per vaginum or on radiology.

- All the patients who are at risk of cervical cancer attending the gynecology OPD routinely.

\section{Exclusion Criteria}

- Females bleeding per vaginum at the time of procedure.

- Patients who have used vaginal medication, vaginal contraceptives, or douches for 48 hours before the sample collection.

- Women who have had their uterus and cervix removed in a hysterectomy.

- Females who were pregnant at the time of screening.

- Patients who have had intercourse the night before the appointment should be avoided.

- Already diagnosed cases of cervical cancer by histopathology.
- All 40 selected women were examined per vaginally and by speculum after acquiring a detailed history and verbal consent from them. The woman was placed in dorsal lithotomy position. After proper positioning of the woman, cervix was viewed by introducing Sims' vaginal speculum and anterior vaginal retractor and external os was identified. Pap smears were made by introducing cervical brush/ cytobrush with a detachable head were inserted into the external os and rotating it through 360 degrees 8-10 times in clockwise direction near the squamo- columnar junction. The cellular material thus obtained was quickly, but gently smeared on a clean glass slide. The glass slide was then immediately put into the Coplin jar containing $95 \%$ ethanol which acted as a fixative. The prepared smears were then stained according to Papanicolaou's technique.

- After staining, slides were mounted, screened under light microscope, and reported according to 2014 Bethesda system.

\section{Results \& Observation}

1. Distribution of benign lesion and epithelial cell abnormalities

\begin{tabular}{|l|c|c|}
\hline Pap smear & No of.cases & $\%$ \\
\hline Total smear & 40 & 100 \\
\hline Inflammatory smear & 25 & 62.5 \\
\hline Epithelial cell abnormality & 15 & 37.5 \\
\hline $\begin{array}{l}\text { Atypical epithelial cells Of -Atypical } \\
\text { squamous cells undetermined } \\
\text { significance [ASCUS] }\end{array}$ & 7 & 17.5 \\
\hline $\begin{array}{l}\text { Atypical squamous cells Cannot } \\
\text { exclude HSIL (ASC-H) }\end{array}$ & 2 & 5 \\
\hline $\begin{array}{l}\text { Low grade squamous intraepithelial } \\
\text { lesion (HPV/mild dysplasia /CIN I } \\
\text { [LSIL] }\end{array}$ & 4 & 5 \\
\hline Malignancy & & \\
\hline
\end{tabular}

Table No. 1 shows that in the present study, 40 pap smears were analyzed showing the distribution pattern of various condition. Out of which Acute inflammatory smear is 25 (62.5\%) and epithelial cell abnormality comprises 15 cases $(37.5 \%)$. 


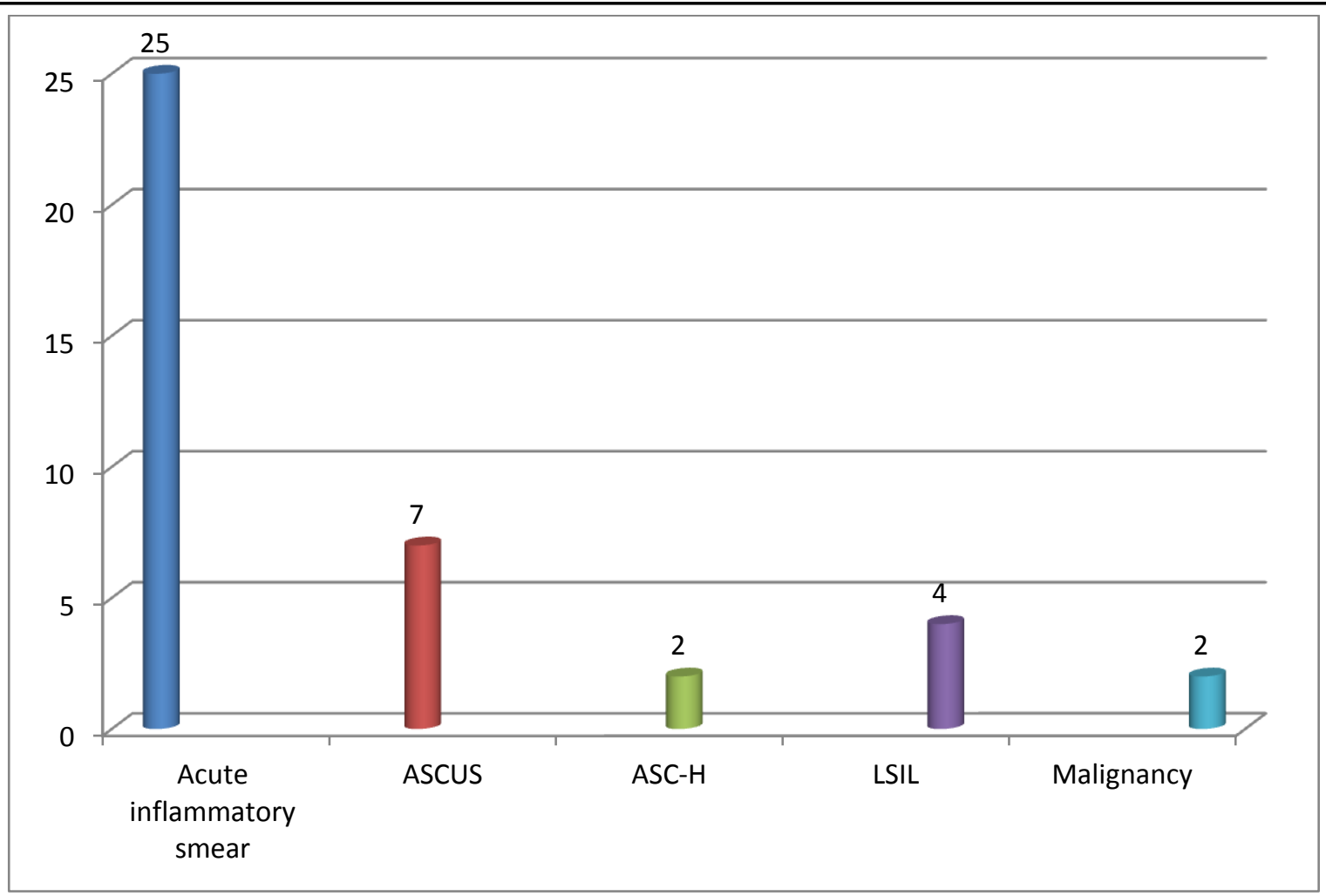

Graph 1- Analysis of pap smear

Table 2 Distribution of Benign lesions and Epithelial cell abnormality

\begin{tabular}{|l|c|c|}
\hline Cytological findings & No. of cases & Percentage\% \\
\hline Negative for intraepithelial lesion or malignancy & 25 & 62.5 \\
\hline Epithelial cell abnormality & 15 & 37.5 \\
\hline Total & 40 & 100.00 \\
\hline
\end{tabular}

Table 2 shows in the present study epithelial cell abnormality is $37.5 \%$.

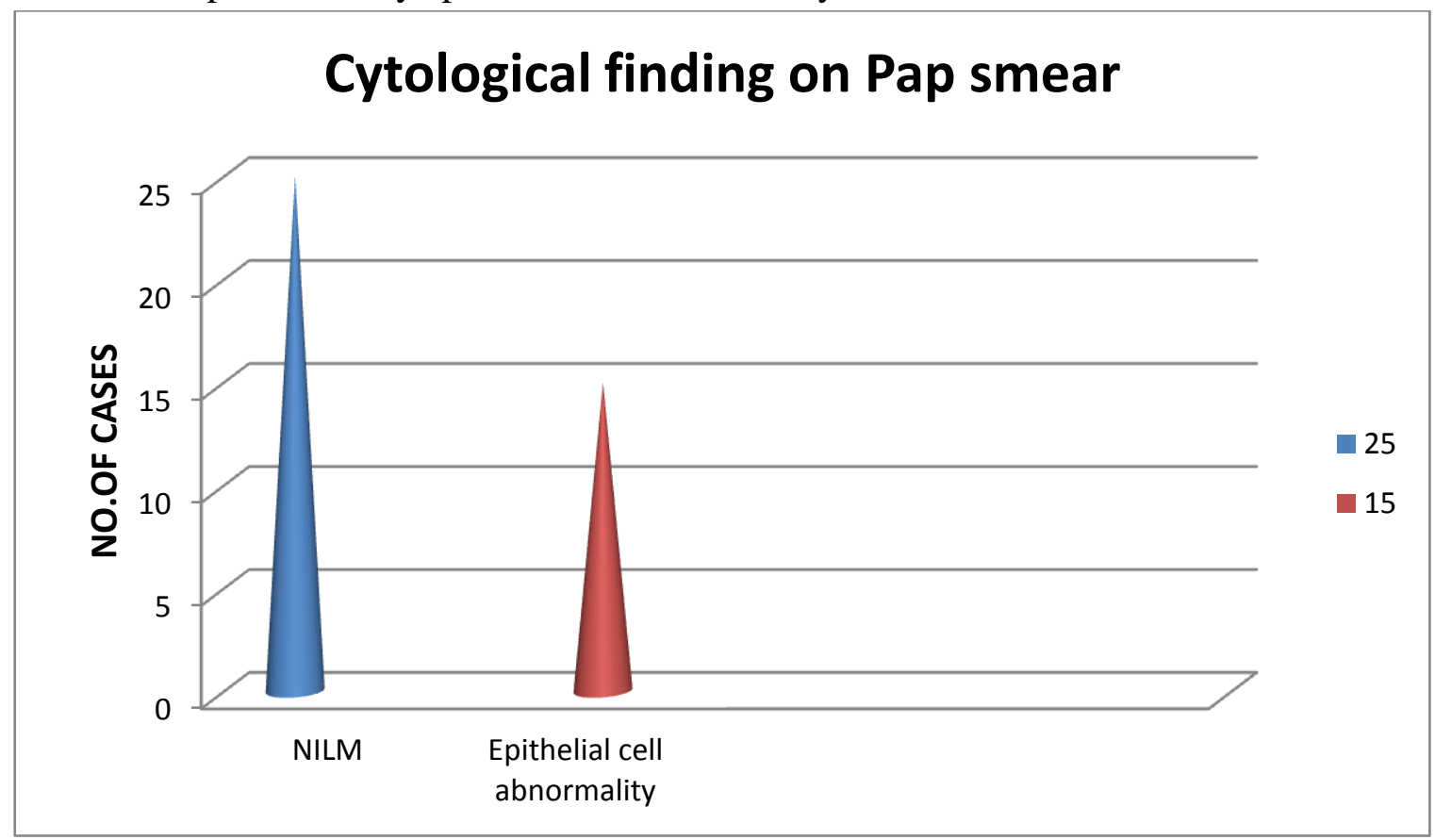

Graph 2 Distribution of NILM and Epithelial cell abnormality. 
3. Distribution of epithelial cell abnormality

\begin{tabular}{|l|c|c|}
\hline Epithelial cell abnormality & $\begin{array}{c}\text { No. of cases } \\
\mathrm{N}=15\end{array}$ & Percentage \% \\
\hline ASC-US & 07 & 46.66 \\
\hline ASC-H & 02 & 13.33 \\
\hline LSIL & 04 & 26.66 \\
\hline SCC & 02 & 13.33 \\
\hline
\end{tabular}

Table No 3 shows out of 15 cases of epithelial cell cannot exclude HSIL, 4 cases shows low grade abnormality, 7 cases show Atypical squamous cells of uncertain significance, 2 cases show squamous intraepithelial lesions. A total of 2 cases Atypical squamous cells of uncertain significance show invasive carcinoma cervix.

\section{Epithelial cell abnormality}

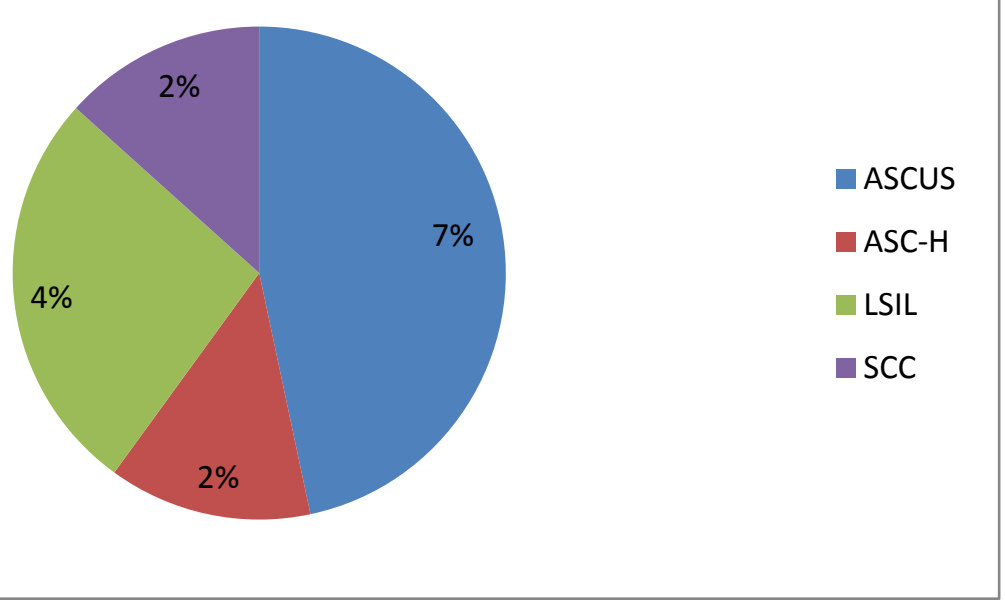

Graph 3 - Distribution of epithelial cells abnormalities

4. Age distribution of the patients having epithelial cell abnormality

\begin{tabular}{|l|c|c|c|}
\hline $\begin{array}{l}\text { Age } \\
\text { years })\end{array}$ & Total cases & NILM & $\begin{array}{l}\text { Epithelial cell } \\
\text { abnormalities }\end{array}$ \\
\hline $15-20$ & 02 & 02 & 00 \\
\hline $21-30$ & 21 & 16 & 05 \\
\hline $31-40$ & 08 & 05 & 03 \\
\hline $41-50$ & 05 & 02 & 03 \\
\hline $51-60$ & 02 & 00 & 02 \\
\hline 61 and above & 02 & 00 & 02 \\
\hline
\end{tabular}

Table No. 4 shows that the bulk of patient belong to age group 21-40 years $29(72.5 \%)$.

5. Age distribution in relation to ASCUS,ASC-H, LSIL and SCC

\begin{tabular}{|l|c|c|c|c|c|c|c|c|}
\hline $\begin{array}{l}\text { Age } \\
(\text { years })\end{array}$ & $\begin{array}{c}\text { ASCUS } \\
\mathrm{n}=7\end{array}$ & $\%$ & $\begin{array}{c}\text { LSIL } \\
\mathrm{n}=4\end{array}$ & $\%$ & $\begin{array}{c}\text { ASC-H } \\
\mathrm{n}=2\end{array}$ & $\%$ & $\begin{array}{c}\text { SCC } \\
\mathrm{n}=2\end{array}$ & $\%$ \\
\hline $15-20$ & 0 & - & 0 & - & 0 & - & 0 & - \\
\hline $21-30$ & 3 & 42.8 & 2 & 50 & 0 & - & 0 & - \\
\hline $31-40$ & 2 & 28.6 & 0 & - & 1 & 50 & 0 & - \\
\hline $41-50$ & 2 & 28.6 & 1 & 25 & 0 & - & 0 & - \\
\hline $51-60$ & 0 & - & 0 & - & 0 & - & 2 & 100 \\
\hline 61 and above & 0 & - & 1 & 25 & 1 & 50 & 0 & - \\
\hline
\end{tabular}

Table no. 5 shows that maximum cases of LSIL whereas maximum cases of carcinoma cervix were detected in 21-30 years of age group and were detected in 51-60 years of age group. 


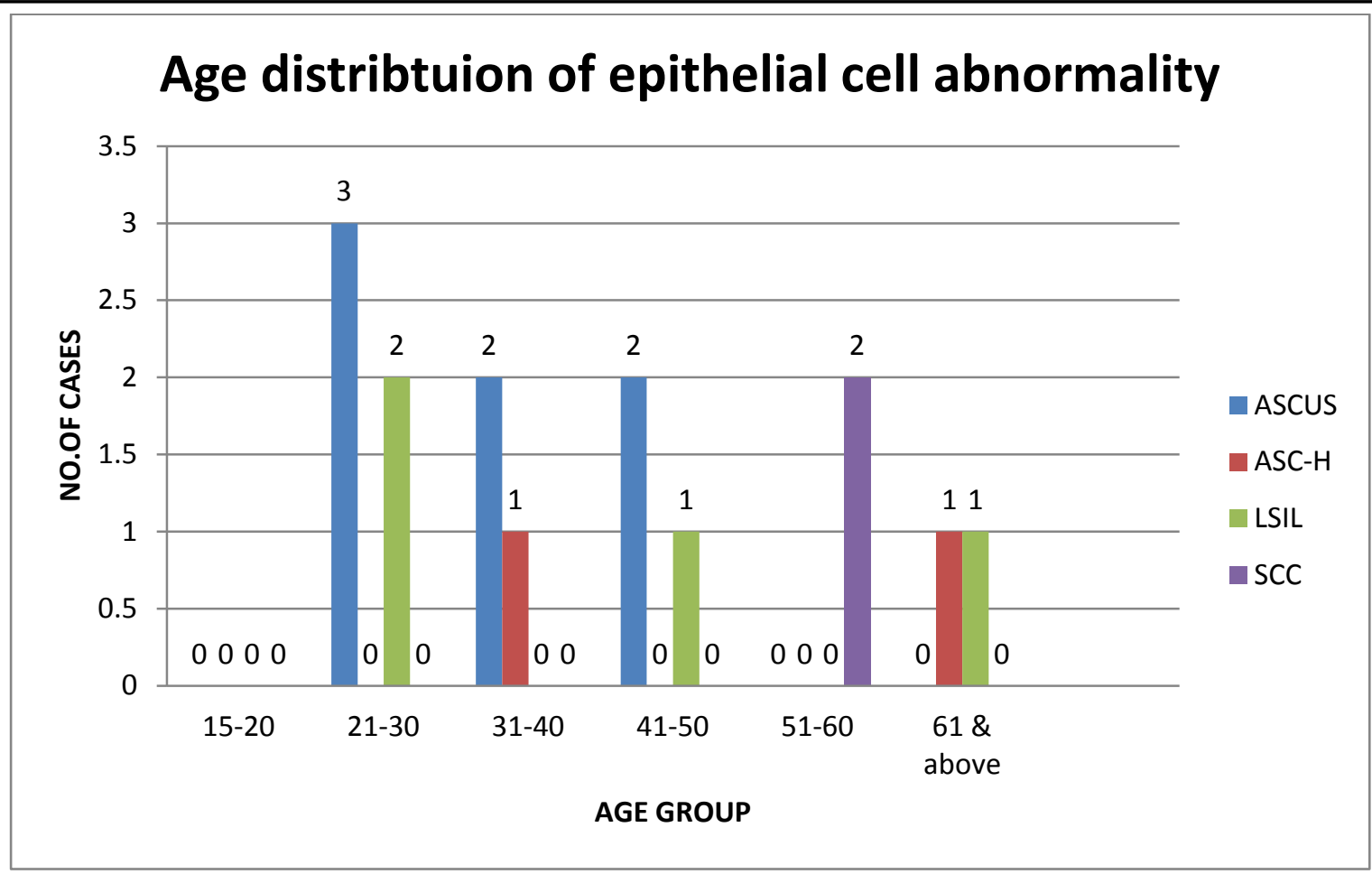

Graph 5 Age distribution of epithelial cell abnormality

6. Distribution of patients according to the complaints for which they visit the clinic

\begin{tabular}{|l|c|c|}
\hline Presenting complaints & No. of patients & Percent (\%) \\
\hline White discharge & 25 & 62.5 \\
\hline Abdominal pain with white discharge & 6 & 15 \\
\hline Burning micturition & 4 & 10 \\
\hline Post coital bleeding & 2 & 5 \\
\hline Bleeding per vaginum & 3 & 7.5 \\
\hline
\end{tabular}

Table no. 6 shows Maximum patients 25 [62.5\%], have complaints of white discharge per vaginum

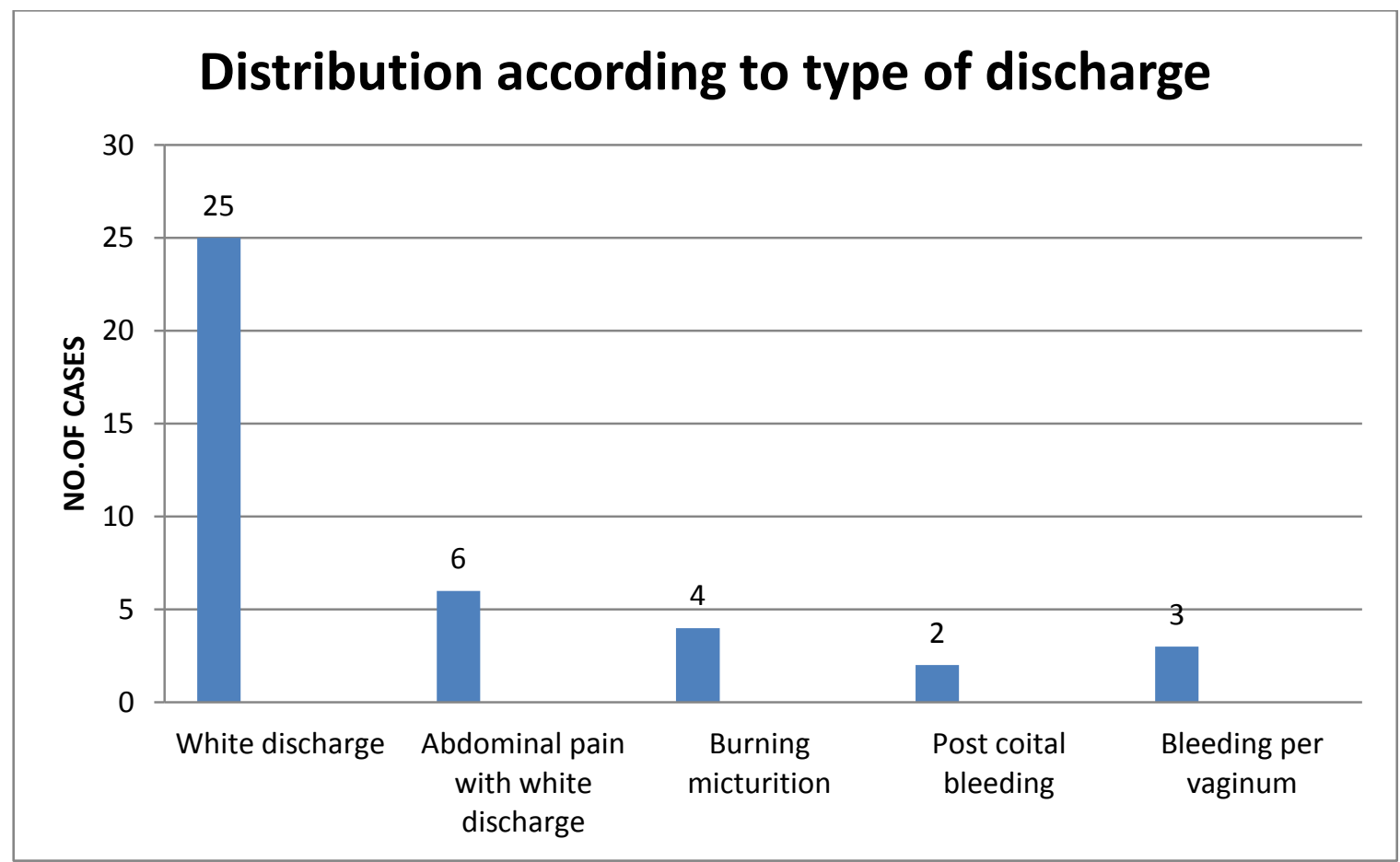

Graph 6 Distribution of patients according to complaints for which they visit 
7. Distribution of the epithelial cell abnormalities in association with the presenting complaints

\begin{tabular}{|l|c|c|c|c|c|c|c|c|}
\hline $\begin{array}{l}\text { Epithelial cell } \\
\text { abnormality }\end{array}$ & $\begin{array}{c}\text { ASCUS } \\
\mathrm{N}=7\end{array}$ & $\%$ & $\begin{array}{c}\text { ASC-H } \\
\mathrm{N}=2\end{array}$ & $\%$ & $\begin{array}{c}\text { LSIL } \\
\mathrm{N}=4\end{array}$ & $\%$ & $\begin{array}{c}\text { SCC } \\
\mathrm{N}=2\end{array}$ & $\%$ \\
\hline White discharge & 5 & 71.4 & 1 & 50 & 3 & 75 & 0 & - \\
\hline $\begin{array}{l}\text { Abdominal pain with } \\
\text { white discharge }\end{array}$ & 0 & - & 1 & 50 & 0 & - & 0 & - \\
\hline Burning micturition & 0 & - & 0 & - & 0 & - & 0 & - \\
\hline Post coital bleeding & 1 & 14.3 & 0 & - & 1 & 25 & 0 & - \\
\hline Bleeding per vaginum & 1 & 14.3 & 0 & - & 0 & - & 2 & 100 \\
\hline
\end{tabular}

Table no.7, shows that $75 \%$ of patient of LSIL presented with white discharge and rest presented with post coital bleeding. While $71.4 \%$ patient of ASCUS presented with white discharge and rest

presented. $100 \%$ cases of carcinoma cervix presented with the complaint of bleeding per vaginum. However, many patients presented with more than one complaint.

8. Distribution of patients according to parity

\begin{tabular}{|l|c|c|}
\hline Parity & No. of cases & Percentage \\
\hline 0 & 04 & 10 \\
\hline 1 & 04 & 10 \\
\hline 2 & 12 & 30 \\
\hline 3 & 16 & 40 \\
\hline 4 and above & 04 & 10 \\
\hline Total & 40 & 100 \\
\hline
\end{tabular}

Table No 8, shows that of out of 40, maximum patients belongs to the parity 2 and above.

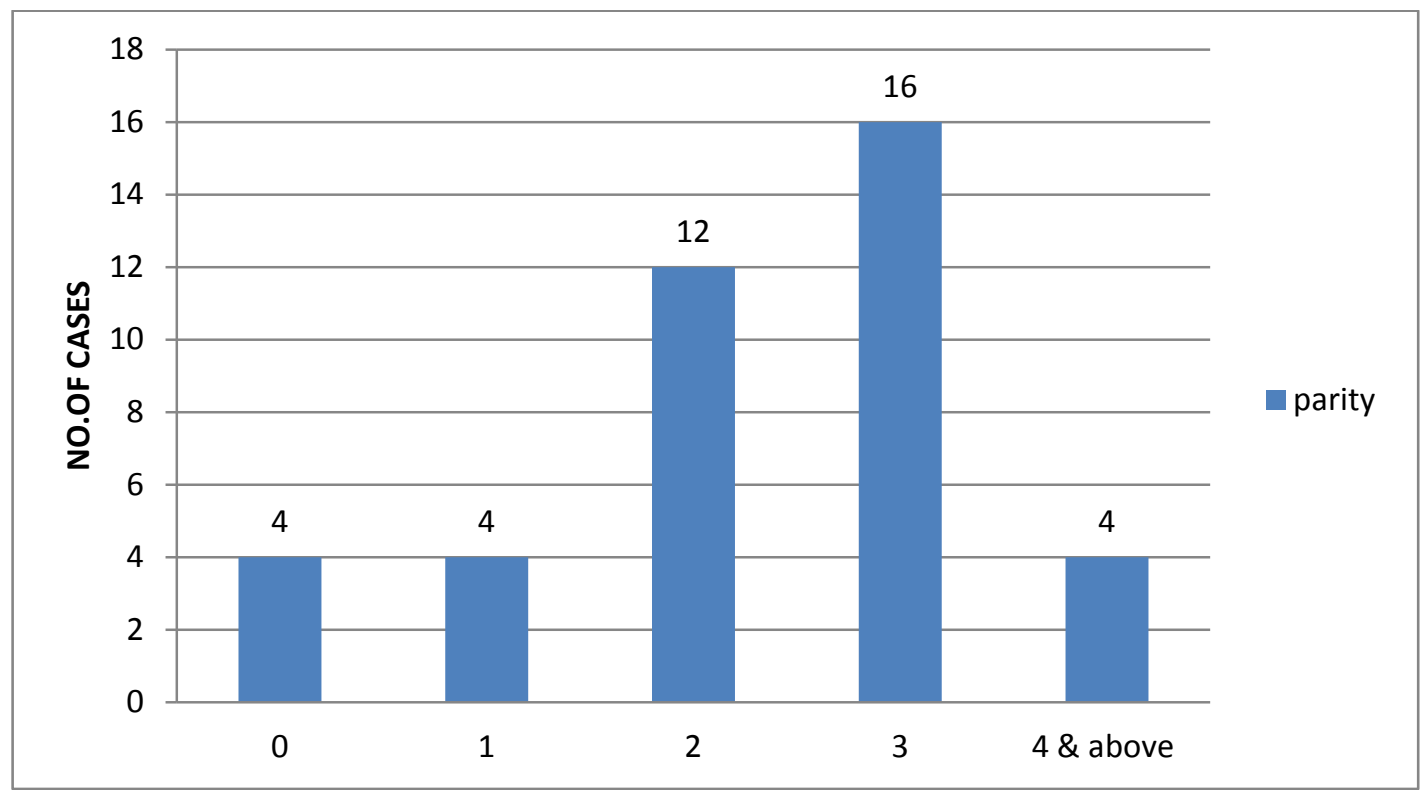

Graph 8 shows distribution according to parity.

9. Relation of parity with epithelial cell abnormalities

\begin{tabular}{|l|c|c|c|c|c|}
\hline Epithelial cell abnormality & ASCUS & ASC-H & LSIL & SCC & TOTAL \\
\hline Parity & & & & & \\
\hline 0 & 0 & 0 & 0 & 0 & 0 \\
\hline 1 & 0 & 0 & 0 & 0 & 0 \\
\hline 3 & 3 & 0 & 2 & 0 & 5 \\
\hline 4 and above & 4 & 1 & 2 & 2 & 9 \\
\hline
\end{tabular}

Table no. 9 shows that significant number of abnormal smear mainly in patients with parity 2 and above. 


\section{Discussion}

The present study comprised of taking cervical samples of 40 symptomatic women attending the outpatient department of Obstretric \& Gynaecology.

Our study revealed ASCUS (17.5\%) to be the most common epithelial cell abnormality. Similar results were obtained in other studies which also concluded that ASCUS to be the most common epithelial cell abnormality ${ }^{[27,28]}$. ASCUS progresses to LSIL, HSIL and SCC. AGUS progresses to adenocarcinoma. ${ }^{[29,30]}$

Table No. 4 shows that the bulk of patient 29 (72.5\%) belong to age group 21-40 years.

Table no. 5 shows that low grade squamous intraepithelial lesion (LSIL) was found in 4 cases $(10.0 \%)$. It was mainly in the age group

21-30 years. Invasive carcinoma cervix was found in 2 cases $(5.0 \%)$. It was mainly in the age group 51-60 years. Age incidence of epithelial cell abnormality by various authors-

\begin{tabular}{|l|c|}
\hline AUTHORS & AGE (in years) \\
\hline $\begin{array}{l}\text { Sunita A. Bamanikar et.al. } \\
(2014)\end{array}$ & $20-75$ years \\
\hline Hemali J. Tailor et.al. ${ }^{[32]}(2016)$ & $25-70$ years \\
\hline Present series 2018 & $\begin{array}{c}\text { LSIL }(21-30 \mathrm{yr}) \\
\text { SCC }(51-60 \mathrm{yr})\end{array}$ \\
\hline
\end{tabular}

The difference in the age incidence of intraepithelial lesions and carcinoma cervix could be due to wide variation in selection criteria.

Table no. 6, As per as the patients presenting complaint was concerned, white discharge was commonest (62.5\%) followed by lower abdominal pain $(15.0 \%)$, burning micturition (10\%), bleeding per vaginum $(7.5 \%)$ and post coital bleeding (5.0 $\%)$.

Commonest complaints by various authors in previous studies-

\begin{tabular}{|l|c|c|c|}
\hline Author & year & $\begin{array}{c}\text { Total no. } \\
\text { of cases }\end{array}$ & $\begin{array}{c}\text { Commonest } \\
\text { complaints }\end{array}$ \\
\hline Aikat et.al. $^{[33]}$ & 1974 & 19574 & $\begin{array}{c}\text { Asymptomatic } \\
(50 \%)\end{array}$ \\
\hline $\begin{array}{l}\text { Juneja et al. } \\
\text { [34] }\end{array}$ & 1993 & 67000 & $\begin{array}{c}\text { Bleeding P/V } \\
(65 \%)\end{array}$ \\
\hline $\begin{array}{l}\text { Manika } \\
\text { Alexander }{ }^{[35]}\end{array}$ & 2015 & 800 & $\begin{array}{c}\text { White discharge } \\
(72 \%)\end{array}$ \\
\hline Our study & 40 & $\begin{array}{c}\text { White discharge } \\
(62.5 \%)\end{array}$ \\
\hline
\end{tabular}

Table no. 8 shows that maximum number of patients belong to parity group 2 and above. Table no. 9 shows that woman with parity 2 or more are at higher risk of developing squamous intraepithelial lesions and carcinomatous changes. Shrivastav P et.al. ${ }^{[36]}$ (1986) Abnormal cytology was detected in $3.6 \%$ of the women in study group (gravid 3 para 2 or more), which was significantly higher than the control (gravid 2 para1), indicating that the former are at higher risk of developing cervical cancer. Juneja A. ${ }^{[37]}$ (1993), high incidence of cervical carcinoma in women with parity $>2$ was noted. Mishra NK et.al. ${ }^{[38]}$ shows that higher parity groups (4 and above) had greater incidence of invasive carcinoma(6.7\%) than those of lower parity groups (1.8\%). Manika Alexander ${ }^{[39]}$ (2015) showed that intraepithelial lesions and malignancy are Nulliparous $19.9 \%$ and Multiparous $80.1 \%$. Women with large number of pregnancies usually start sexual life early and the early age of first intercourse might be etiologically more important than number of pregnancies. The period of early squamous metaplasia is the time of greatest risk for cellular transformation and for the development of cervical neoplasia. Early squamous metaplasia is most frequent in puberty, early adolescence and first pregnancy. Therefore, women who begin sexual activity at an early age when the metaplastic process is most active would have a greater chance of developing cervical cancer.

In nulliparous women, cervical neoplasia is not very common. Hence multiparity is a high risk factor for the development of premalignant and malignant lesions, because of chronic infection, repeated birth trauma, poor personal care, poor nutrition and hygiene etc. Early marriages are still common in our country and hence exposure to coitus and repeated child births at an early age are also common. High parity usually means a young age at marriage and first pregnancy.

One of the significant discrepancies between our study and the previously published data from other countries is the higher rate of ASCUS and lower rate of LSIL. We assume that as the women included in our study were routinely screened 
and/or re-screened, they presented with an early form of cytological interpretation in the cervical smear, and thus, ASCUS rate was higher. Most common age to develop carcinoma cervix is between 51-60 years and the precursor lesions occur 5 - 10 years prior to developing invasive cancer. So a test which is detecting more women who are at risk for cervical carcinogenesis should be started as screening test so to drop down the incidence of deadly cervical cancer.

\section{Conclusion}

Cervical cytology is method for early detection of intraepithelial lesions and malignancy and therefore should be established as a routine diagnostic aid. The study reveals that the cases of cervical cancer can be detected at early stage if there are proper education and awareness in the society.

\section{Bibliography}

1. Lindsey A. Torre; Freddie Bray; Rebecca L. Siegel; Jacques Ferlay; JoannieLortetTieulent; AhmedinJemal. Global Cancer Statistics, 2012. CA CANCER J CLIN 2015;65:87-108: 99-100.

2. Bojgua $\mathrm{S}$; Kldiashvili E. Liquid Based Cytology Cervical Cancer Screening Program - Georgian Experience. Arch Can Res. 2016, 4: 3.

3. Ekane, G.E.H et al. (2015) Pap smear Screening, the Way Forward for Prevention of Cervical Cancer? A Community Based Study in the Buea Health District, Cameroon. Open Journal of Obstetrics and Gynecology, 5, 226-233.

4. GakidouE; Nordhagen $\mathrm{S}$; Obermeyer $\mathrm{Z}$ (2008) Coverage of cervical cancer screening in 57 countries: Low average levels and large inequalities. Plos Med 5(6): e132. Doi:10.1371/journal. Pmed.0050132.

5. BasuPartha; ChowdhuryDebjani. Cervical cancer screening \& HPV vaccination: a comprehensive approach to cervical cancer control. Indian J Med Res 130, September 2009, pp 241-246.

6. Naylor Bernard. The century for cytopathology. Actacytol 2000;44:709725.

7. Sánchez-Anguiano LF, Alvarado-Esquivel C, Reyes-Romero MA, Carrera- Rodríguez M. Human papilloma virus infections in women seeking cervical Papanicolaou cytology of Durango, Mexico: Prevalence and genotype. BMC Infec Dis 2006;6:2733.

8. García-Piñeres AJ, Hildesheim A, Herrero R, Trivett M, Williams M, Atmetlla I, et al. Persistent human papillomavirus infection is associated with a generalized decrease in immune responsiveness in older women. Cancer Res 2006;66:110706.

9. Patil V, Wahab SN, Zodpey S, Vasudeo ND. Development and validation of risk scoring system for prediction of cancer cervix. Indian J Public Health 2006;50:3842.

10. Juneja A, Sehgal A, Mitra AB, Pandey A. A survey on risk factors associated with cervical cancer. Indian J Cancer. 2003 JanMar;40:15-22.

11. Mukherjee BN, Sengupta S, Chaudhuri S, Biswas LN, Maiti P.A. case-control study of reproductive risk factors associated with cervical cancer. Int J Cancer. 1994 Nov 15;59:476-82.

12. Gawande V, Wahab SN, Zodpey SP, Vasudeo ND. Risk factors for cancer cervix: a case control study. Indian J Cancer. 1998;35:164-70.

13. Aparajita Dasgupta, Narendra N Naskar, Rama Ram, Sila Deb A. Community Based Study On The Prevalence Of Risk Factors OF Cancer Cervix In Married Women Of A Rural Area Of West Bengal Year. Indian journal of community medicine 2002;27:35-38. 
14. International

Collaboration

of

Epidemiological Studies of Cervical Cancer, Appleby P, Beral V, Berrington de González A, Colin D, Franceschi S, Goodhill A, et al. Cervical cancer and hormonal contraceptives: collaborative reanalysis of individual data on 16,573 women with cervical cancer and 35,509 women without cervical cancer from 24 epidemiological studies. Lancet 2007;370:1609-21.

15. Smith JS, Bosetti C, Munoz N, Herrero R, Bosch FX, Eluf-Neto J, et al. IARC Multicentric Cervical Cancer Study Group. Chlamydia trachomatis and invasive cervical cancer: A pooled analysis of the IARC multicentric case-control study. Int J Cancer 2004;111:431-9.

16. Richardson $\mathrm{H}$, Abrahamowicz M, Tellier PP, Kelsall G, du Berger R, Ferenczy A, et al. Modifiable risk factors associated with clearance of type-specific cervical human papillomavirus infections in a cohort of university students. Cancer Epidemiol Biomarkers Prev 2005;14: 1149-56.

17. Lai CH, Chao A, Chang CJ, Chao FY, Huang HJ, Hsueh S, et al. Host and viral factors in relation to clearance of human papillomavirus infection: a cohort study in Taiwan. Int J Cancer 2008;123:1685-92.

18. Tortolero-Luna G. Epidemiology of genital human papillomavirus. Hematol Oncol Clin North Am 1999;13:245-57.

19. Kjaer SK, Chackerian B, van den Brule AJ, Svare EI, Paull G, Walbomers JM, et al. High-risk human papillomavirus is sexually transmitted: Evidence from a follow-up study of virgins starting sexual activity (intercourse). Cancer Epidemiol Biomarkers Prev 2001;10:101- 6.

20. Schiffman M, Castle PE, Jeronim J, Rodrigue AC, Wacholde S. Human papillomavirus and cervical cancer.Lancet. 2007;370:890-

907. [PubMed]
21. Van den Brule AJC, Walboomers JMM, du Maine M, Kenemans P, Meijer CJLM. Difference in prevalence of human papillomavirus genotypes in cytomorphologically normal cervical smears is associated with a history of cervical intraepithelial neoplasia. Int $\mathbf{J}$ Cancer 1991;48: 404-8.

22. Resnick RM, Comelissen MTE, Wright DK, Eichinger GH, Fox HS, ter Schegget $\mathrm{J}$, et al. Detection and typing of human papilloma virus in archival cervical cancer specimens by DNA amplification with consensus primers. J Natl Cancer Inst 1990;82:1477-84.

23. Patil V, Wahab SN, Zodpey S, Vasudeo ND. Development and validation of risk scoring system for prediction of cancer cervix. Indian J Public Health 2006;50:3842.

24. Gupta P et al. Visual Inspection of the Cervix with Acetic Acid and Pap smear Test in Cervical Cancer Screening. IOSR Journal of Dental and Medical Sciences (IOSR-JDMS) e-ISSN: 2279-0853, pISSN: 2279-0861.Vol 14, Issue 11 Ver. V (Nov. 2015), PP 38-4.

25. Miller AB, Chamberlain J, Day NE, Hakama M, Prorok PC. Report on a workshop of the UICC project on Evaluation of Screening for Cancer. Int $\mathbf{J}$ Cancer 1990;46:761-9.

26. Walton RJ. The task force on cervical cancer screening programs. Can Med Assoc J 1976;114:981

27. Patel M.M., Pandya A.N., Modi J. Cervical pap smear study and its utility in cancer screening, to specify the strategy for cervical cancer control. National Journal of Community Medicine; vol 2, issue1, 2011.

28. Ghaith J.E., Rizwana B.S. - Rate of Opportunistic Pap smear Screening and Patterns of Epithelial Cell Abnormalities in Pap Smears in Ajman, United Arab 
Emirates. Sultan Qaboos Univ Med J; 12(4): 473-478, 2012.

29. Khan MS, Raja FY, Ishfaq G, Tahir F, Subhan F, Kazi BM et al. Pap smear Screening for Precancerous conditions of the cervical cancers. Pak J. Med. Res.

30. Edelman M, Fox A. Cervical Papanicolau smear abnormalities in inner Bronx adolescents: Prevalence, progression, and immune modifiers. Cancer (cancer cytopathology). 1999;87:184-9.

31. Sunita A. Bamanikar, Dadaso S. Baravkar, Shirish S. Chandanwale, Prachet Dapkekar, Study of Cervical Pap Smears in a Tertiary Hospital, Indian Medical Gazette - JULY 2014

32. Hemali J. Tailor, Patel R.D., Prashant R. Patel*, Vasudha M. Bhagat. Study of cervical pap smears in a tertiary care hospital of south Gujarat, India Tailor HJ et al. Int J Res Med Sci. 2016 Jan;4(1):286-288.

33. Aikat, M., Gupta, S. \& Aikat, B. K. Critical evaluation of cervical cytology. Indian J. Med. Res. 62, 655-661 (1974).

34. Juneja, A. et al. Selective cervical cytology screening: discriminant analysis approach. Neoplasma 40, 401- 404 (1992).

35. Manika AlexanderA, Ronald KhanapurB Study On Profile Of Patients Undergoing Pap Smear At A Tertiary Centre In Jabalpur, National Journal of Medical and Dental Research, July-September 2015: Volume-3, Issue-4, Page 206-212

36. Selective screening for cancer of the cervix uteri in South Indian women. Shrivastav P, Jairaj P, Balasubramaniam N, Krishnaswami H. Abstract Int J Gynaecol Obstet. 1986 Oct;24(5):33742PMID:2880766
37. Selective cervical cytology screening: discriminant analysis approach. Juneja $A^{1}$, Murthy NS, Sharma S, Shukla DK, Roy M, Das DK. Neoplasma. 1993;40(6):4014.PMID:8289972 Chronic cervicitis Etiology of cervical inflammation

38. Cytologic screening for the detection of cancer in the uterine cervix - a survey in Patna (India). Mishra NK, Sinha TK.Cancer Lett. 1990 Jun 30;52(1):217.PMID: 2354415

39. Manika Alexander A, Ronald Khanapur B Study On Profile Of Patients Undergoing Pap Smear At A Tertiary Centre In Jabalpur, National Journal of Medical and Dental Research, July-September 2015: Volume-3, Issue-4, Page 206-212. 